\title{
Risk Analysis of Harmful Gas in Deep Buried Long Tunnel Construction
}

\author{
ZHAO Yanxi ${ }^{1, a}$, JIA Caihong ${ }^{1, b}$ \\ ${ }^{1}$ School of Architecture Engineering, Nanjing Institute of Technology, Nanjing 211167, China \\ ayanxi009@163.com, b463680134@qq.com
}

Keywords: Deep buried tunnel; construction; harmful gas; risk analysis.

Abstract. The emergence of harmful gas will bring serious difficulties to the tunnel construction, improper handling can easily lead to accidents. In order to evaluate the possibility of harmful gas in the tunnel, the basic characteristics of harmful gas in tunnel are analyzed from three aspects, that is spatial distribution, inflammable and explosive property, and harm to human body. Based on domestic and foreign research data, the case of harmful gas is listed, and the potential harmful gas is discussed. According to the engineering case, the lithology and geological structure of harmful gas is analyzed. Harmful gases are mainly distributed in the semi hard rock and organic matter rock formations, harmful gas is also prone to gather in the deep rock mass fracture zone, the joint and fracture zone. In order to deal with the harmful gas, we should strengthen the prediction and monitoring, and early detection. At the same time, take ventilation, pressure, grouting and other measures to deal with the harmful gases. The study could provide an effective reference for the similar projects. This research has some practical value and social significance.

\section{Introduction}

Deep buried long tunnel usually pass through the complex geological conditions, a series of special geological disasters often encountered in the construction process, such as rock burst, harmful gas, high pressure water gushing, high temperature etc.. The harmful gas is one of the problems of deep buried long tunnel geological disasters, and have been more and more paid attention to.

Harmful gas in tunnel engineering is usually refers to gas, methane $\left(\mathrm{CH}_{4}\right)$, carbon dioxide $\left(\mathrm{CO}_{2}\right)$, hydrogen sulfide $\left(\mathrm{H}_{2} \mathrm{~S}\right)$ and ammonia gas. These harmful gases occur frequently in the coal bearing strata of relatively closed structures, and may also occur in non coal strata. Because of sudden ejection, burning or explosion, harmful gases not only do harm to human health, but also deteriorate the tunnel construction conditions, and causing catastrophic damage.

Such as Alper diversion tunnel which is $48.3 \mathrm{~km}$ long, has occurred six times large eruption. In one eruption, there escaped $150000 \mathrm{~m}^{3}$ gas in a day and night, the eruptions also formed many large holes, the maximum volume is more than $2500 \mathrm{~m}^{3}$, far beyond the design roof outline. Italy Appenine long tunnel has occurred four times gas explosion, the tunnel was shut down for seven months.

Many China's railway tunnels have met large amount of gas eruption or explosion, resulting in serious economic losses, only in Yanjiaozhai tunnel, more than 70 people were killed because of gas explosion. Therefore, it is very important to strengthen the research on the characteristics of harmful gas in deep buried long tunnel.

\section{Basic characteristics of harmful gases}

Underground harmful gases mainly is methane $\left(\mathrm{CH}_{4}\right)$, hydrogen sulfide $\left(\mathrm{H}_{2} \mathrm{~S}\right)$, oxygen air and the construction of carbon monoxide (CO), nitrogen oxide and sulfur dioxide $\left(\mathrm{SO}_{2}\right)$, dust, etc.. They have significant spatial distribution and explosive properties.

The spatial distribution characteristics. In tunnel, the lightest gas is methane, its specific gravity is only 0.55 , often rich in the vicinity of the tunnel roof. If there is a concentration of methane gas in the tunnel, methane can occur at the top of the tunnel. Followed by carbon monoxide , its specific gravity is 0.967 , slightly lighter than air, often distributed in the upper part of the tunnel, and the proportion of hydrogen sulfide carbon dioxide, sulfur dioxide is 1.19, 2.3 and 1.53, usually concentrate in the middle and near the bottom of the tunnel. Aiming at the characteristics of the 
spatial distribution of the main harmful gas in the tunnel, ventilation and exhaust pipe should be arranged in the construction of the tunnel.

Inflammable and explosive characteristics. Underground flammable and explosive gas mainly are methane, carbon monoxide, hydrogen sulfide, etc.. Once the content of these gases in the air reaches a certain range, it may explode under the condition of fire. Methane will explode if its content reach to $5 \% \sim 15 \%$, especially when its content is $8 \%$, it will appear the most explosion , and when the content of methane in the air is greater than 15\%, it will not explode, and the limited explode content of hydrogen sulfide in the tunnel air is $4.3 \% \sim 45.5 \%$. It is obvious that the explosion limit of methane is the least, followed is hydrogen sulfide and carbon monoxide.

Harm to human health. Tunnel harmful gas will affect the health of construction workers directly, and even threaten the construction workers safety. Once carbon monoxide in the tunnel reached $1 \%$ to $2 \%$, the human body has a sense of discomfort, the content of $3 \%$ to $4 \%$ will lead to the rise of human blood pressure, headache, if the content reach to $7 \%$, it can lead to death in a few minutes. The effect of harmful gas on human health can be evaluated by the index of poisoning. The study shows that the limits of the toxic effects of different harmful gases on human health are different. The impact of the main harmful gases on the human body is shown in Table 1

Table 1 Impact of main harmful gases on the human body

\begin{tabular}{|c|c|c|c|c|c|}
\hline Name & $\begin{array}{c}\text { Poisoning } \\
\text { index } \\
\left(n \times 10^{-6}\right)\end{array}$ & Impact & Name & $\begin{array}{l}\text { Poisoning index } \\
\quad(\mathrm{ppm})\end{array}$ & Impact \\
\hline $\mathrm{CO}$ & $\begin{array}{l}<300 \\
<900 \\
<1200\end{array}$ & $\begin{array}{c}\text { No effect } \\
\text { Headache, vomiting } \\
\text { Life danger }\end{array}$ & $\mathrm{H}_{2} \mathrm{~S}$ & $\begin{array}{l}100 \sim 150 \\
600 \\
700\end{array}$ & $\begin{array}{c}\text { Mild symptoms in few hours } \\
\text { Have life risk } \\
\text { Can be choked to death }\end{array}$ \\
\hline $\mathrm{NO}_{2}$ & $\begin{array}{c}5 \\
50 \\
100 \sim 150 \\
>200\end{array}$ & $\begin{array}{c}\text { A strong odor } \\
\text { Cause breathing } \\
\text { Pulmonary edema } \\
\text { Life risk }\end{array}$ & $\mathrm{SO}_{2}$ & $\begin{array}{c}6 \sim 12 \\
20 \\
50 \sim 100 \\
400 \sim 500\end{array}$ & $\begin{array}{l}\text { Nose and throat irritation } \\
\text { Have a stimulating to the eyes } \\
\text { Can withstand } 30 \sim 60 \text { minutes } \\
\text { Life danger }\end{array}$ \\
\hline
\end{tabular}

According to table 1, we should strengthen the tunnel ventilation in the construction, and carry on real-time monitoring based on harmful gas type and concentration, and protect the health of the construction personnel effectively.

\section{Domestic and international hazardous gas harmful gases}

The harmful gas in domestic and foreign tunnel is shown in table 2.

Table 2 Case of harmful gas in domestic and foreign tunnel

\begin{tabular}{|c|c|c|c|}
\hline Country & Tunnel name & Geological condition & Harmful gas characteristics \\
\hline \multirow{5}{*}{ China } & $\begin{array}{c}\text { Yuntai } \\
\text { Mountain tunnel }\end{array}$ & Coal measure strata & Large amount of gas \\
\hline & Yanjiao tunnel & Coal measure strata & Gas pressure up to $0.406 \mathrm{MPa}$ \\
\hline & $\begin{array}{l}\text { Samut LADA } \\
\text { tunnel }\end{array}$ & $\begin{array}{c}\text { Cretaceous red sandstone and } \\
\text { mudstone }\end{array}$ & A lot of gas outburst \\
\hline & Baiyun tunnel & $\begin{array}{l}\text { Fault fracture zone, coal bearing } \\
\text { formation }\end{array}$ & Gas, hydrogen sulfide \\
\hline & Qinling tunnel & Gneiss, Granite & Gas explosion \\
\hline \multirow{2}{*}{$\begin{array}{l}\text { Former } \\
\text { Soviet } \\
\text { Union }\end{array}$} & $\begin{array}{l}\text { Xie Wan Alper } \\
\text { tunnel } \\
\end{array}$ & Basalt & Gas eruption \\
\hline & $\begin{array}{l}\text { Zeqi diversion } \\
\text { tunnel } \\
\end{array}$ & Shale, sandstone & Methane \\
\hline Italy & $\begin{array}{l}\text { Carbocaine } \\
\text { tunnel }\end{array}$ & Conglomerate, silt & $\mathrm{CH}_{4}(0.61 \%) 、 \mathrm{H}_{2} \mathrm{~S}(0.08 \%), \mathrm{NO}_{2}(24 \%) ;$ \\
\hline
\end{tabular}




\begin{tabular}{|c|c|c|c|}
\hline $\begin{array}{c}\text { UK - } \\
\text { France }\end{array}$ & Channel Tunnel & Coal measure strata & Methane \\
\hline \multirow{2}{*}{ U.S.A } & Tecolote tunnel & $\begin{array}{c}\text { Conglomerate, sandstone, fine } \\
\text { sandstone and mudstone }\end{array}$ & Methane and hydrogen sulfide \\
\cline { 2 - 4 } & $\begin{array}{c}\text { Losangeles } \\
\text { Metro Tunnel }\end{array}$ & Sandstone & Methane and hydrogen sulfide \\
\hline Japan & $\begin{array}{c}\text { New Ningjin } \\
\text { tunnel }\end{array}$ & Mudstone, tuff & Methane, hydrogen sulfide and ammonia \\
\hline
\end{tabular}

\section{Geological conditions of harmful gases}

It can be seen that the composition, concentration and emission of harmful gases in the underground are closely related to the rock properties and mineral composition of the tunnel. Explosive gas mainly distribute in coal, bitumen rock formation. Toxic gases often exist in the place of new volcanic source and intense crustal fracture a activity belt, in the place of organic compounds, the groundwater often overflow with hydrogen sulfide.

Stratigraphic lithology. Whether there is harmful gas depends on the stratum lithology. Such as methane is often distribute in organic clay, shale oil and other areas. Through the analysis of domestic and foreign literatures, the harmful gas mainly distributed in semi hard rock and rich in organic matter and other special ingredients, such as rock with coal bearing strata, but hard rock generally no harmful gas disaster development.

Geological structural conditions. Whether the harmful gas can cause damage depends on a certain concentration and storage conditions. Only part gas can remain in the coal seam, most gas is lost to the atmosphere or dissolved in groundwater circulation. Under favorable geological conditions the methane is preserved and the methane will be transferred to the coal seam with a high porosity of the deposit layer within the appropriate site. Therefore, the main factors that determine the storage of harmful gases are the geological structure and the thickness of the overburden. The most suitable situation for the harmful gas reservoir is anticline (or dome).In addition to the structure of the fault, the fault zone in the rock mass, especially the deep fracture zone, active volcanic activity source or the intense surface active area, also often become harmful gas migration and enrichment site.

\section{Prediction and control of harmful gas}

Prediction of harmful gases. Prediction of harmful gas is still empirical. For tunnel engineering, as far as possible to avoid coal measures strata or oil storage structure during the line selection, and strengthen the early warning monitoring, this kind of disaster can be avoided. According to the geological conditions of harmful gas development, geological mapping, drilling, hole depth and remote sensing interpretation can be carried out in the tunnel engineering geological exploration, which may lead to geological prediction of hazardous gas disasters along the tunnel.

Harmful gas comprehensive control. (1) Strengthening monitoring and ventilation measures. Once the harmful gas is proved to exist, especially containing the flammable and explosive methane and hydrogen sulfide. Monitoring system should be established to continuous and regular predict the gas. In the monitoring process, not only to monitor the concentration of harmful gases, but also to pay attention to its value, while strengthening ventilation measures to reduce the concentration of gas.

(2) Working surface reduction measures. If the there is high pressure and large capacity harmful gases at working face, advance boreholes, auxiliary pilot or shafts should be carried out, to prevent the gas and rock erupted or cause catastrophic explosion.

(3) Sealing measures. In the construction, the use of sealing measures mainly depends on the content of harmful gas, pressure At present there are two main types: lining and grouting. At present, the most common and simple method is to use concrete lining, so that the concrete lining become a low permeability barrier. In order to prevent the harmful gas leaking, the lining or special design section of the lining can be used to reduce the pressure of the tunnel lining. Grouting measures in 
engineering is often used to stop water plugging and soil reinforcement, the grouting material is cement. The cement grouting can greatly block rock mass cranny pore. So it is suitable for the sealing of the harmful gas. However, cement injection can not seal the cracks of less than $0.15 \mathrm{~mm}$, and therefore can not completely prevent the infiltration of harmful gases into the tunnel. Therefore, to achieve better control of harmful gas, it is better to use the low viscosity chemical materials to carry on Secondary Grouting.

In addition to take the above treatment measures, safety measures are the most important, the construction unit uses the following safety emergency plan:

Strengthening the education and training of blasting knowledge. Hire experts to teach blasting knowledge, so that all construction and management personnel to understand blasting knowledge, pay attention to security matters, technical points, blasting personnel must be documented appointment.

Try to shorter tunnel face exposed time, promptly apply the initial support, close excavated part, to avoid the gas concentration is too high.

Strengthen the tunnel construction management, tunnel construction should be vigilant, prohibit the use of fire and smoking.

\section{Conclusions}

The emergence of harmful gas has brought great difficulties to the construction of highway tunnels, and the handling of the accidents can easily lead to accidents. Therefore, it is possible to establish a harmful gas monitoring system, timely detection and effective monitoring of harmful gases. In the tunnel of harmful gas, we should take many kinds of management and safety measures, so as to ensure the safety and health of the construction personnel in the tunnel.

Limited to the current level of geological prospecting technology and the understanding level of shallow natural gas, it is difficult to find out the low pressure and low volume fraction of gas in the exploration stage, and cannot forecast and predict the distribution, volume fraction and emission of the gas in the formation qualitatively and quantitatively.

Based on the analysis of the geological environment in the tunnel acrossing area, the construction risk sources are identified, the corresponding preventive measures are taken, and the risk points are monitored and analyzed, the construction risk can be resolved by taking preventive measures.

\section{Acknowledgements}

This work was financially supported by the Nanjing Institute of Technology high level introduction talent scientific research start funds(No:YKJ201430) and Nanjing Institute of Technology scientific research funds(QKJA2010008).

\section{References}

[1] Zhou Xuesheng: Technical Information, Vol. 2 (2014), p. 40-43.

[2] Meng Xin and Liu Lei: Urban Rail Transit, Vol. 46 (2011), p. 20-23.

[3] Zhang Hao, Zhao Zicheng, Liu Jianming, et al: Highway, Vol. 10 (2014), p. 274-279.

[4] Shao Junjiang, Wang Guoxin: West-China Exploration Engineering, Vol. 19 (2006), p. 5.

[5] Sun Wei: Sci-Tech Information Development and Economy, Vol. 17 (2007), p. 288-289. 